\title{
Antik Yunan Siyasal Düşünüşünde İnsan Doğası ve Toplum Anlayışı: Platon ve Aristoteles ${ }^{*}$
}

\author{
OLKAN SENEMOĞLU** \\ olkansenemoglu@gmail.com
}

\begin{abstract}
Özet: Bu çalışma Platon ve Aristoteles'in insan doğası ve toplum anlayışına odaklanmaktadır. Bu iki düşünürün insan doğasını ve toplumu nasıl açıkladıklarına değinip, onların siyaset teorilerindeki yönetim anlayışlarında insan doğası ve topluma dair çıkarımlarının yerinin ne olduğu tartışılmaktadır. Buna göre Platon ve Aristoteles insanların doğaları gereği belli özelliklere sahip olduğu anlayışında ortaklaşmaktadırlar. Aynı şekilde ikisi de insanların doğuştan getirmiş olduğu bazı yetenekler olduğuna ve bu yeteneklerin insanların almış oldukları eğitimle geliştirilmesi gerektiği fikrinde aynı noktada bulunmaktadırlar. Diğer taraftan iki düşünüründe toplumu gerekçelendirme biçimleri aynıdır. Hem Platon hem de Aristoteles, insanların kendilerine yeten bir varlik olmamalarından ve bir başkasına gereksinim duymalarından dolayı toplum içinde yaşamak zorunda olduklarını düşünür. Platon ve Aristoteles arasındaki farklılıklara bakılacak olursa; Aristoteles, Platon’un varsaydiğı idealar dünyasından bahsetmez. Ayrica her insanın kendi içinde onu en iyiyi gerçekleştirmeye götüren bir ereğinin olduğunu söyler. Böylece insanların bir araya getirip kurdukları devletin de iyi bir devlet olduğu fikrine ulaşır. Platon kendi düşünmüss olduğu devlet modelinde insanların mayalarına göre toplumda iş yapmaları ve eğitim almaların düşünürken, Aristoteles, doğrudan bazı insanların doğuştan akliyla her şeyi sezebilen bir varlik olduğu için yönetici, bazllarının ise doğuştan bedensel kuvvetlerinin olması nedeniyle yönetilen olması gerektiğini düşünür.
\end{abstract}

Anahtar kelimeler: Platon, Aristoteles, İnsan, İnsan doğası, Toplum, Devlet, Yönetim.

\section{Giriş}

Antik Yunan'da siyasal yapı, bugünün modern toplumunda çoğu zaman karşılaşılan ulus devlet modelinden farklı olarak, her ihtiyacını kendi karşılayabilen "polis”ler üzerine kuruludur. "Yunan polisi Batıdaki en erken siyasal organizasyon biçimlerinden biridir ve Yunan polisi, modern ulus devletin tam karşısında yer alır." ${ }^{1} \mathrm{Bu}$ anlamda politika (politeia, yani şehir hayatı ama aynı zamanda erklerin düzeni ya da anayasa) polis'den türemiş bir terimdir. ${ }^{2}$ Ekonomik düzen ise birçok alanda kölelerin çalıştığı bir yapıya sahiptir. Boş zamanlarda ise halkın katılımıyla agoralarda polisin

\footnotetext{
* Bu makale "Marx’ın Düşüncesinde İnsan Doğası ve Toplum” başlıklı doktora tez çalışmamdan yararlanılarak oluşturulmuştur.

** Dr.

1 Donald Tannenbaum, David Schultz, Siyasi Düşünce Tarihi: Filozoflar ve Fikirleri, çev. Fatih Demirci, 4. bs. (Ankara: Adres Yayınları, 2008), 31.

2 Christian Ruby, Siyaset Felsefesine Giriş, çev. Aziz Ufuk Kılıç, (İstanbul: İletişim Yayınları, 2012), 13.
} 
işlerinin tartışıldığı bir sosyal alan vardır. Antik Yunan Atina’sında halkın tabakalaştığını da görmek mümkündür. Genel olarak üç tabakadan bahsedilebilir: "Atina’da sosyal tabakalaşmayı, eupatridea denen aristokratlarla, thet denen halk sınıfı, metoikos adı verilen yabancılar ve 'Köle' sınıfı oluşturmaktaydı. Bu sınıflardan, eupatridea, thet ve metoikoslar özgür insanlardan oluşuyordu."3 Fakat metoikoslar için hukuki bir vatandaşlık söz konusu değildir. Köleler gibi bunların da şehrin siyasi hayatında yeri yoktur. ${ }^{4}$

İște böyle bir yapıya sahip toplumda anlaşılacağı üzere insanların çok keskin çalışma alanları vardır. Böyle bir toplumun düşünürü olan Platon ve Aristoteles'in toplum ve insan anlayışına ve buradan hareketle de yönetimin ne olması gerektiği sorusuna verdikleri yanıtlara bu şartların bir etkisinin olabileceğini düşünmek güç olmasa gerek.

$\mathrm{Bu}$ çalışma yukarıdaki tartışmalardan hareketle Platon ve Aristoteles'in insan doğası ve toplum anlayışlarına odaklanmaktadır. Köleliğin meşru görüldüğü, yöneten ve yönetilenin keskin olarak belirlendiği bir toplumda, insanların yaptığ 1 işlerin doğal bir süreç olduğu fikri de haliyle normalleşmiş olur. Bundan dolayı Platon, insanın doğuştan mayası neyse ona uygun olacağı fikrini ileri sürer. Bu durumda da insanın mayasını aşması neredeyse imkansız gibi görülür. Fakat Platon, insanın genel olarak eğitimle, özeldeyse kendi mayasına uygun eğitilmesiyle dizginlenebileceğini ileri sürer. $\mathrm{Bu}$ anlamda Platon ve Aristoteles'in eğitim anlayışları da insanı kavrama biçimlerine göre şekillenir. Platon'da eğitimci bir çoban rolündedir. Çünkü sürüyü idare eden çoban nasıl ki sürünün niteliğine göre kararlar alır, o zaman eğitimci de elindeki kişinin doğasını bilip ona göre davranmalıdır. Örneğin Platon’a göre, iyi bir duvarcı veya iyi bir çiftçi olmak için insanlar oyuncak evlerle oynatılmalıdır v.b.. Buna göre bütün herkesin ne yapacağı onların mayalarının tespit edilmesiyle birlikte belirlenebilir ve kimin yönetici olacağı da buna göre belli olur. Platon buradan hareketle toplumu, insanların mayalarına göre eğitildiği ve herkesin ne yapacağının belli olduğu bir birlik olarak kurgular. Ayrıca, toplumun oluşmasındaki nedeni Platon insanın tek başına kendine yetememesiyle açıklar.

Aristoteles de tıpkı Platon gibi insanın belirli özelliklerle dünyaya geldiğini ve eğitimle değiştirilebileceğini düşünür. Fakat varlıkların dünyada bulunma nedenini veya bulunma biçimlerini Platon gibi bir yansıma olarak değil, içlerinde gerçekleştirmeleri gereken bir erek olduğunu düşünerek ele alır. İnsanlar içlerindeki bu erekten dolayı en iyiyi gerçekleştirmeye yazgılıdırlar. Bundan dolayı insanların oluşturacakları devletler veya yönetimlerde iyidirler. Böylece Aristoteles, insanların topluluk ve devlet oluşturma biçimlerini de bir doğallık olarak düşünür. Ayrıca insanlar doğaları gereği yöneten ve yönetilen olarak belirirler.

3 TÜBA, Ulusal Açık Ders Malzemeleri, Eski Yunan'da Siyasal-Sosyal-Kurumsal Yapı, Yöntem ve Teoriye Dair, haz., Bican Şahin, (1997), 7. (erişim 28.08.2016).

4 George Sabine, Siyasal Düşünceler Tarihi 1: Eski Çă̆-Orta Çağ, çev. Harun Rizatepe (Ankara: Türk Siyasi İlimler Derneği Yayını, 1969), 3. 


\section{Platon'un İnsan Doğası ve Toplum Anlayışı}

Atina'da İ.Ö. 420'de doğan Platon, “siyaset üzerinde sistematik olarak eğilen ilk antik

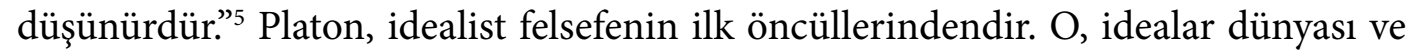
duyu dünyası diye iki dünyanın var olduğundan bahseder. İdealar dünyası, asıl gerçek olan bu dünya, tek tek nesnelerin özünü barındırır. İdealar dünyası hep aynıdır, değişim ve devinim yoktur. Var olmak için başka bir şeye ihtiyaç duymazlar. Çünkü varoluşları kendilerindendir. Felsefenin görevi bunun böyle olduğunu ispatlamak veya onu anlamaktır. Duyu dünyası ise sürekli değişim içinde olan nesnelerin var olduğu ve meydana gelip yok olan şeylere tanık olunan dünyadır. Dolayısıyla Platon'un duyu dünyası dediği dünya, bir yansıma olup hakikatin kendisi değildir. Bu doğrultuda Platon'un bu çıkarımları onun idealist düşünme biçiminin öncüleri arasında olmasını sağlarken, siyasal yaşama getirmiş olduğu fikirler de döneminin revizyonist bir çok fikrinden farklıdır. Zira Platon siyasal yaşamın var olan kalıplarının yeniden düzenlenmesiyle ilgilenmez; aksine, onları, kendisinin toplumun amacıyla -üyelerinin erdeme ve böylece kapasiteleri ölçüsünde mutluluğa ulaşacakları koşulların sağlanması- ilgili devrimci anlayışına uygun yeni bir düzenle değiştirmekle ilgilenir. ${ }^{6}$

Peki, böyle bir dünyada insan ve doğası nasıldır? Toplum nasıl kurgulanır? Kendi siyasal sistemi insan doğası ve toplum anlayışıyla ne kadar bağlantılıdır? Platon kendi siyasal düşüncesinin merkezin insanı yerleştirir. Platon'un bu fikri, hocası Sokrates'ten aldığını söylemek yerinde olacaktır. "Platon, hocası Sokrates'ten felsefenin yüzünün insana dönük olması, eğer felsefi etkinlikten söz edilecekse bunun merkezine insanın konulması gerektiğini çok iyi öğrenmişti.”7

Antik Yunan düşünürleri insan doğası fikrini, insanın iyi veya kötü bir öze sahip olup olmadığını ele alarak ve böyle bir özden bahsedilebiliyorsa, eğitimin bu öze etkisinin ne olacağ üzerinde durarak tartışmışlardır. Bunun belirgin bir örneği Platon'un Devlet isimli kitabında görülmektedir. Bu konuyla ilgili, Sokrates'in Platon'un kardeşleri Adeimantos ve Glaukon ile aralarında geçen konuşmalar özellikle dikkat çekicidir. Glaukon'a* göre, doğru dediğimiz kimseler, haksızlık edemedikleri için doğru olmaya çalışanlardır ve bu kimseler doğru olmayı kendi istekleriyle yapmazlar. Buradan hareketle Glaukon, kanun zoruyla insanın eşitlik ilkesini benimsemesi gerektiğini söylemeye mecbur kalır. Glaukon’a göre, birisi bir gücü eline geçirince, bu gücü ele geçirmeden önce ister iyi, erdemli olsun; isterse kötü ve erdemsiz fark etmez, ikisi de aynı yolu izleyecektir.

\footnotetext{
5 Christopher Rowe, "Platon: İdeal Devlet Biçiminin Arayıș”, Siyasal Düşüncenin Temelleri, der. Brian Redhead, çev. Erkan Akın, (İstanbul: Alfa Basım Yayın, 2001), 17.

6 Rowe, "Platon: İdeal Devlet Biçiminin Arayıșı", 21.

7 Filiz Zabcı, "Büyük Sokratesçi Okullar ve Siyaset”, Sokrates'den Jakobenlere Batida Siyasal Düşünceler, Ed. Mehmet Ali Ağaoğulları, 5. bs. (İstanbul: İletişim Yayınları, 2015), 91.

* Bu çalışmada ve Platon'un metinlerinden yapılan alıntılarda geçen Glaukon, Platonun kardeşidir. Platon metninde Glaukon'u ve diğer aktörleri konuşturarak kendi fikirlerini aktarır. Burada Glaukon’a veya diğer tartışmacılara aitmiş gibi sunulan görüşler, aslında Platon’a aittir. Ayrıca benzer şekilde şunu da hatırlatmak gerek: Platon'un kitaplarından aktaracağımız alıntılar çoğunlukla diyalog şeklinde geçmektedir ve diyaloglarda hangi düşüncenin Platon'a veya Sokrates’e ait olduğunu kestirmek zor olduğu için, söz konusu fikirlerin hem Platon'un hem de Sokrates'in fikirleri olduğunu göz önünde bulundurmakta fayda var.
} 
"Bir doğru, bir de eğri adam alalım, ikisine de dilediklerini yapmak fırsatını verelim. Sonra da artlarına düşüp eğilimlerinin onları nereye götüreceğine bakalım. Göreceğiz ki, doğrunun gittiği yer, eğrinin de gittiği yer olacak; çünkü kendinde olandan fazlasını istemek, bunu iyi bir şey sayıp ardına düşmek, insanın doğuşunda olan bir şeydir. İşte, onu bundan alıkoyan, eşitlik saygısına götüren kanundur."

Glaukon, pek bilindik bir efsaneye başvurarak bu durumu açıklamaya çalışır; adil olan ile olmayana tanıdı̆̆ımız serbestçe davranma imkânı, insanların doğalarını Gyges’in sahip olduğu güce sahip olmaları halinde gayet güzel ortaya çıkacağını ileri sürer. Bu efsaneye göre: Gyges, Lidya kralının hizmetindeki bir çobanmış, günün birinde bir sağanak ve bir deprem yüzünden yer çatlamış, hayvanların otladığı yerde derin bir yarık açılmış. Bunu görünce, şaşakalan çoban, yarığın içine inmiş ve orada görülmedik birçok güzel şeyler arasında, içi oyuk, üstü delik deşik, tunçtan bir at görmüş. Eğilip içine bakmış atın, insan boyundan büyük bir ölü görmüş; ölünün parmağındaki altın yüzükten başka bir şeyi yokmuş. Bu yüzüğü alıp yukarı çıkmış. Çobanlar, her ay sonunda olduğu gibi, krala hesap vermek için toplandıklarında, Gyges bu toplantıya parmağındaki yüzükle gelmiş. Otururken yüzügüün taşını farkına varmadan avucunun içine çevirmiş. Bunu yapar yapmaz da yanında oturanlar kendisini görmez olmuşlar, nereye gitti diye soruşturmaya başlamışlar. Şaşakalmış herkes. Yüzükle oynarken taşı çevirince gene göze görünür olmuş. Böylece işi çakan Gyges, yüzüğün tılsımını denemiş, bakmış ki yüzüğün taşını çevirince görünmez oluyor, düzeltince görünüyor. Bunun üzerine saraya girenlerin arasına katılmanın yolunu bulmuş. Sarayda kralın karısını baştan çıkarmış, onun yardımıyla kralı öldürüp yerine geçmiş. ${ }^{9}$

Sokrates'in de fikirlerine itiraz etmediği Glaukon'a göre (bu diyalog Sokrates ve Glaukon arasında geçmektedir) böyle bir güç kimin eline geçerse geçsin, bu gücü herkes kendi istediği doğrultuda kullanacaktır:

"Şimdi böyle iki yüzük olsa, birini doğru adamın, birini de eğri adamın parmaklarına taksak ve şehre koyuversek, bunlar, her istediklerini korkmadan alacaklar, evlere girip gönüllerinin hoşlandığı kimselerle düşüp kalkacaklar, canları kimi isterse öldürecek, kimi isterse hapisten kurtaracak, tıpkı bir Tanrı gibi dilediklerini yapacaklar. İkisinin de davranışı bir olacak; çünkü, bu durumda hiç kimse, doğruluğa bağlı kalacak, başkalarının malına el sürmeyecek kadar babayiğit olamaz!"10

Glaukon'a göre bu örnek, insanın kendi isteğiyle değil, zorlanarak doğru olduğunu göstermektedir. Bu doğrultuda Platon'a göre "haksızlık etmek fırsatını bulan herkes haksızlık eder. Doğruluksa, doğruya hiçbir kar sağlamaz." ${ }^{11}$ Bu şekilde görüşünü dile getiren Platon aslında insanın çoğu zaman kötülük yapmaya meyilli olduğunu söylemektedir.

8 Platon, Devlet, çev. Sabahattin Eyüboğlu-M. Ali Cimcoz, 3.bs. (İstanbul: Remzi Kitabevi, 1975), 51.

9 Platon, Devlet, 51.

10 Platon, Devlet, 51-52.

11 Platon, Devlet, 52. 
Yukarıda anlatılan çoban hikayesinden hareketle, insanın doğası Glaukon'a göre, insanın erdemli, ahlaksız, hırsız olup olmamasından bağımsız hep kötülüğe yönelmektedir. Efsanede anlatılan çoban pek de erdemli birisi olabilir veya bir başka erdemsiz kişi de olsa, söz konusu olan yüzügü kim takarsa taksın erdemlerini veya ahlaksızlıklarını bir kenara bırakıp aynılaşacaktır.

Şimdi kısaca buradaki örnekten hareketle insanın sürekli kötülüğe yöneleceği yönündeki fikri ele almaya çalışalım. Örneğin; çoban o yüzüğü bulunduğu toplum yararına kullansaydı bu durumda ne olacaktı? Niçin illa insanlar kötülüğe yönelecektir? "İnsanlar ister erdemli ister erdemsiz olsun uygun koşullar eline geçtiğinde kesinlikle iyi davranacaktır" deseydik ne olurdu? Veya Platon neden bunu düşünmez? Düşünmez çünkü eğer düşünseydi bu durumda, bütün bir sistemi çökecekti. Zira insanlar adaletli olmak için kurallara ihtiyaç duyar gibi bir öneri ortaya koyması için öncelikle insanların doğaları ne olursa olsun mümkün olduğunda kötülüğe yöneleceklerini ispat etmesi gerekir. Platon'un tartışmalarından da gördügüumüz gibi insan doğası kurgusu veya insanın ne olduğuna yönelik tutum, düşünürler için siyasal düşünce sistemlerini veya felsefelerini temellendirmeleri için hayati önemdedir. Örneğin yukarıdaki Glaukon ve Sokrates arasındaki diyalog üzerinden fikirlerine ulaşmış olduğumuz Platon'un aksine, Rousseau da kendisine şu soruyu sorar: "Acaba Gyges'in yüzüğü bende olsa ne yapardım?” İnsanın iyilik mi yoksa kötülük mü ederek mutluluğa erişeceği konusunda Rousseau'nun görüşüne de başvurmakta fayda var. Rousseau, Yalnız Gezerin Hayalleri isimli kitabının Altıncı Gezi bölümünde görüşünü: "Biliyorum ve hissediyorum ki, iyilik etmek insan yüreğinin duyabileceği mutlulukların en gerçeğidir” diyerek belirtmektedir. ${ }^{12}$ Glaukon'un insanın iyi veya kötü olup olmadığına bakmaksızın, gücü eline geçirince keyfine göre davranacağı ve bunun da hep kendi çıkarına yöneleceği yönündeki kanı, Rousseau'da tam tersi bir karşılık bulur. Zira, Rousseau; "insana mutluluk veren en büyük şey iyilik etmektir" demektedir:

“Tanrı gibi göze görünmez olsaydım ve her şeyi yapmaya gücüm yetseydi, onun gibi iyi ve hayırlı olurdum. İnsanlar, güç ve özgürlük sayesinde en iyi örneklerini çıkarırlar; düşkünlük ve tutsaklık ancak kötü insanlar yaratmıştır. Gyges'in yüzüğü bende olsaydı beni insanlara baş eğmekten kurtarır, onları egemenliğim altına kordu. Düşleme daldığım zamanlar, o yüzüğü nasıl kullanırdım diye çok düşündüm; herhangi bir durumu kötüye kullanmak isteği, işte, erke öyle bir fırsatta yaklaşır; bütün dileklerimi yerine getirmek gücü ve her şeyi yapma olanağı olan bir kimsenin beni aldatamayacağına emin olunca, ondan sürekli olarak ne isteyebilirdim acaba? Ancak şunu: Herkesi hoşnut görmek"13

İşte buradan hareket eden Rousseau, insanın doğuştan ne kral ne de herhangi bir şey olduğunu söylerken, Platon, insanın mayası neyse ona göre eğitilmesi ve bu doğrultuda dikkatli olunması gerektiğini söylemektedir. Bu tartışma aynı zamanda filo-

12 Jean-Jacques Rousseau, Yalnız Gezerin Hayalleri, çev. Reşat Nuri Darago, (İstanbul: MİV, 1944), 74.

13 Rousseau, Yalnız Gezerin Hayalleri, 82. 
zofların kendi siyasal sistemlerini veya anlayışlarını oluştururken, insan doğasına ve toplum anlayışlarına dair görüşlerinin ne kadar önemli olduğunu göstermektedir.

Platon'un insan ve doğasına dair görüşleri çoğu zaman çelişkili görünmektedir. İnsan kendi mayasına göre mi, yoksa eğitimle mi en iyi şekilde var olur? Hangisini savunduğunu söylemek zor ama ikisini de savunduğunu söylemek neredeyse kesindir. Zira, eğitimle şekillenen insan fikri üzerinde durduğu gibi, insanın doğuştan tunç veya altın gibi bir mayayla doğduğunu da söylemektedir. Platon, kesinlikle zorunlu eğitimin olması gerektiğini düşünür. Platon’a göre, "gymnasium”ların, atıcılık ve okçuluk eğitimlerinin yanı sıra 'babası isteyen okula devam eder, istemeyen eğitimi bırakır' diye bir şey söz konusu olamaz, ama dendiği gibi 'her erkek adam' babasından çok devletin malı olduğu için, elden geldiğince zorunlu olarak eğitim görecektir." ${ }^{14}$ Çünkü Platona göre çocuk, bütün vahşi hayvanlar içinde en azgınıdır;

"Çünkü zeka pınarı henüz düzene oturmamışken, kurnaz, yaramaz ve bütün hayvanların en taşkınıdır. İşte bu nedenle onu birçok dizginle gemlemeli: Başlangıçta bakıcısının ve annesinin elinden çıktığında, daha çok genç ve toy olduğu için lalaların eline, sonra da ona özgür bir insana yakışan her türlü bilgiyi öğretecek öğretmenlerin eline teslim edilmeli." ${ }^{\prime 5}$

Görüldüğü üzere Platon insanın zekâsının düzene sokulması gerektiğini, eğitimle çocukların "uygun” bilgilerle donatılmasını öngörür. Bu nedenle gün doğup sabah olunca çocuklar öğretmenlerine gönderilmeli çünkü, "ne koyun ne de başka bir sürü hayvanı çobansız yaşayamadığı gibi, çocuklar lalasız, köleler de efendisiz yaşamamal1." ${ }^{16}$ Platon'un eğitimciye bir çoban görevi yüklemesi boşuna değildir. Çünkü eğitimci çocuğa işinin erdemini öğretecektir. Platon, başarılı olmak isteyen bir kimsenin çocukluğundan itibaren amacına uygun şeylerle uğraşmasının doğru olduğunu düşünür. Sözgelişi “iyi bir duvarcı iyi bir çiftçi olmak istiyorsa, duvarcı, oyuncak evlerle oynamalıdır, çiftçi de bunun için yapmalıdır..." Eğitimci de bu oyunlar aracılığıyla "çocukların hazlarını ve tutkularını büyüdüklerinde hedef olarak seçecekleri yere yöneltmelidir." ${ }^{17}$ Görüldüğü üzere, yukarıda insanın eğitimle ehlileşeceğini söyleyen Platon, şimdi de eğitimle insanın alanında uzmanlaşabileceğini, diğer bir değişle işinin erdemlerini öğreneceğini söylemektedir. Bu anlayış fikirlerini Aristoteles'le paralellik göstermektedir.

Şimdi insanın ta çocukluktan eğitilmesi gerektiğini söyleyen Platon`un Devlet metninde tartıştıklarına bakmakta yarar var. Bütün bir kentin insanlarını doğuştan herkesin farklı mayalarla doğduğu fikrine inandırmaya çalışacağını ve buna inanıp inanmayacaklarının kaygısını yaşamaktadır:

"Bu toplumun birer parçası olan sizler, diyeceğim, birbirinizin kardeşisiniz. Ama, sizi yaratan Tanrı, aranızdan önder olarak yarattıklarının mayasına altın katmıştır. Onlar bunun için baş tacı olurlar. Yardımcı olarak yarattıklarının

14 Platon, Yasalar, çev. Candan Şentuna-Saffet Babür, c. 2, 2. bs. (İstanbul: Kabalcı Yayıevi, 1998), 23. 15 Platon, Yasalar, 28.

16 Platon, Yasalar, 28.

17 Platon, Yasalar, 26. 
mayasına gümüş, çiftçiler ve öbür işçilerin mayasına da demir ve tunç katmıştır. Aramızda bir hamur birliği olduğuna göre sizden doğan çocuklarda her halde size benzeyeceklerdir. Ama arada bir, altından gümüş, gümüssten de altın doğduğu olabilir. Tanrı, her şeyden önce önderlere, doğan çocuklara iyi bekçilik etmelerini, içlerine bu madenlerden hangilerinin katılmış olduğunu dikkatle araştırmalarını buyurmuştur. Kendi çocukları tunçla ya da demirle katışık doğmuşlarsa hiç acımayıp, hamurlarına uygun işlere koyacak onları; çiftçi ya da işçi yapacak..." ${ }^{18}$

Şimdi Platon`un pek tartışmadığı bazı konuların üzerinde durmak gerekiyor. İnsan eğer belirli bir mayayla doğmuşsa o zaman bunu fark etmezsek ne olur, zaten mayasına uygun olarak davranmak zorunda kalmayacak mıdır? Bu durumda eğitim bir işe yarar mı? Veya kişinin mayası uygun değilse eğitim verilse de mayasına ters bir gelişim sergileyemeyeceği için bütün bir eğitim verme işi boş bir uğraş olmayacak mıdır? Acaba Platon'un anne, babalara kendi çocuklarının tunçla ya da demirle katışı doğmuşlarsa hamurlarına uygun işlere verilmesi gerektiğini söylerken kastettiği şey acaba şöyle bir şey midir? Örneğin arpa ve pirinç tohumlarını tarlasına ekecek olan bir çiftçiyi düşünelim, eğer bu çiftçi pirinci de aynı arpa gibi soğuk ve kuru bir araziye ekerse aynı verimi alamayacaktır. Ama arpayı kendi doğasına uygun pirinci de kendi doğasına uygun bir araziye ekerse daha verimli sonuçlar alacaktır. Nitekim Platon, bir yerde de "insanlar yaradılıştan birbirine benzemezler. Kimi şu işe, kimi bu işe daha yatkındır" demektedir. ${ }^{19}$ Veya şurada dile getirdiği düşüncede olduğu gibi "demek oluyor ki yurdu koruyacak adam, yaradılışı bakımından filozof, azgın, çevik ve güçlü olacak." ${ }^{20}$ Ama bir insan her şeyde başarılı olabileceğini düşünmez Platon. Ona göre "bir insanın aynı zamanda hem şair, hem de oyuncu olamayacağını da söyleyebiliriz."21 Fakat modern çağ şunu göstermektedir insanlar tek başlarına bir işin uzmanı olmaktan çok kimi zaman yeterli bir çabayla farklı farklı mesleklerde de başarı sağlamaktadır. Bir bankacı güzel bir ressam, veya bir doktor iyi bir şarkıcı olabilmektedir. Eğer Platon'un bahsettiği şey tam da arpa ve pirinçte olduğu kadar kesin doğalara sahip insan olma durumuysa, burada gözden kaçırdığı nokta şüphesiz böyle algılanan veya böyle bir doğaya sahip olduğu düşünülen insanların kesinlikle siyasal bir birlik oluşturamayacağıdır. Çünkü insanın tam da siyasal bir varlık veya siyasal bir hayvan olmasının nedeni kendi doğasını zorlayabilmesi onu aşabilecek bir yapıya sahip olabilmesidir. İște birazdan göreceğimiz gibi insanın doğasına dair bu statik fikrin karşısında Aristoteles farklı bir insan doğası sunarak Platon'un fikrinden ayrılacak ve insanın siyasal bir hayvan olduğu fikrine ulaşacaktır.

Yukarıda ifade edildiği gibi insanın doğuştan bir şeylere yatkın doğduğunu söyleyen Platon, insanın koşullarının; insanın nasıl hissettiğini, hatta nasıl bir davranış sergileyeceğini belirlediğini düşünür. "Dört bir yanımızdan zurna sesi gelirse, kulaklarımızdan içimize oluk oluk, yumuşak, tatlı, hüzünlü makamlar akıtılırsa, bütün ömrümüz türkü mırıldanmakla geçer. En büyük keyfi türkü söylemekte bulursak, 
içimizdeki sert coşkunluk, demirin ateşte yumuşadığı gibi yumuşar."22 Platon’a göre, sürekli müzik dinleyen birisinin içi büsbütün yumuşayp eriyeceği için sonunda yiğitliği de yok olur. İçi bu kadar gevşeyen birisinden de sünepe bir savaşçı çıkacaktır. Ve insan "doğuştan coşkun değilse, bu gevşeme daha da çabuk olur. Ama doğuştan güçlüyse, duygularındaki coşkunluk gitgide azalır, olur olmaz yerde kırılır, gevşer, patlar, söner."23 İște Platon ın bu tarz tartışması onun neyi ön plana çıkardığını görmemizi engellemektedir. Doğuşunda yiğitlik varsa da yoksa da fark etmez, çünkü maruz kaldığ 1 şeyler onu gevşetebilir, doğamızda varsa sadece bu süreç biraz daha uzun sürmektedir. Ama kimi yerde de insanın doğuştan belirli bir özellikle yaratıldığını söylemesi bir karışıklık yaratmaktadır. Örneğin "tabiatın kimi insanları filozof ve devlet adamı olarak, kimini de düşünmeden söyleneni yapacak insanlar olarak yarattığını" söylediği gibi. ${ }^{24}$ Şu cümle de başka bir görüş ortaya koymaktadır: "İyi adam olmak kolay iş değildi; önce insanın doğuştan bir üstünlügü olacak diyorduk, çocukken hep güzel şeylerle oynayacak, sonra kendini bütün güzel şeyleri öğrenmeye verecek." 25

İşte Platon>un düşüncesinde tam olarak belirsiz kalan şey budur: İnsanın yaratılışı $\mathrm{ml}$, yoksa daha sonra ki eğitimi mi belirleyici olandır? Örneğin şu konuşmada eğitim yaratılışı belirlemektedir: "Sertlik insanın içindeki coşkunluktan gelse bile, eğitim yoluyla yiğitliğe çevrilebilir. Ama sertlik aşırı bir hale gelirse, çekilmez bir kabalık doğurur."26 Veya yine aynı yerde yalnız bedenlerinin gelişimiyle ilgilenenler mesela sadece jimnastikle uğraşanlar gereğinden çok sert, yalnız müzikle uğraşanlarsa, kendilerine yakışmayacak kadar gevşek olurlar, diyerek insanın yine mevcut koşullarıyla değişebileceğine dikkat çeker. Ayrıca insanın isteklerini ele alırken yaptığı tartışmaya bakacak olursak: Platon, insanın zorunlu ve zorunlu olmayan isteklerinden bahseder ve ona göre zorunlu olmayan örneğin sevişme isteği gibi istekler, çocukken aldığımız eğitimle atılabilir isteklerdir. Ama zorunlu istekler, örneğin yeme isteği ise insanın içinden atamayacağ türdendir. ${ }^{27}$

Platon, devletlerin ve toplumların tıpkı insanlar gibi karakterleri olduğunu, ayrıca devlet ve topluluğun karakterinin kendi üyelerinin karakterleriyle aynı olduğunu düşünür. O zaman Platon’a göre devletin karakterini insanlardan aldığ̣ söylenebilir. Bu durumu şöyle örneklendirir: "Sertlikleriyle Trakyalıların... Bilim tutkusu da bizim memleketin özelliği sayılabilir. Fenikelilerle Mısırlılardaysa hemen göze çarpan bir para tutkusu vardır."28

Peki, toplumun oluşmasına ne neden olmaktadır veya Platon’a göre insanlar niçin bir arada yaşarlar? Bu soruya vermiş olduğu yanıt kendisinden sonra gelen birçok düşünürün yanıtıyla aynı gibidir: "Toplumu yapan, insanın tek başına kendi kendine yetmemesi, başkalarını gereksemesidir. Yoksa toplumun kurulmasında başka bir

22 Platon, Devlet, 101.

23 Platon, Devlet, 101.

24 Platon, Devlet, 163.

25 Platon, Devlet, 242.

26 Platon, Devlet, 100.

27 Platon, Devlet, 243.

28 Platon, Devlet, 125. 
sebep var mı?"29 Platon bu fikriyle toplumu yapay bir kurum olarak gören sofistlerin karşısında durmuş oluyor.

Platon, devleti de ana bölümlerine ayırır. Buna göre, devlet, koruyucular, çiftçiler ve zanaatkarlar vb. ile yöneticiler olmak üzere üç sınıfa ayrılır. Ve bu sınıfta bulunacak insanlar kendi mayalarına göre seçilecek ki o devlet yıkılmadan ayakta uzun yıllar kalabilsin ve insanlar da mutluluğu tadabilsinler. Ve bu yönetim Platon'a göre, iyiler yönetimidir, çünkü yöneticiler iyidir. Onların iyiliği ise kendi çıkarlarını değil toplumun çıkarlarını gözetmekten gelir: "İyiler, ne para için yönetmeyi üzerlerine alırlar, ne de şeref için; yönetmelerine karşılık, ücret isteseler kendilerine ücretli uşak, yönetmenliklerinden faydalanarak gizlice para çekecek olsalar hırsız derler diye korkarlar. Şeref için de razı olmazlar bu işe; çünkü, düşkün değildirler şerefe." ${ }^{30}$ Peki, bu iyiler yönetiminin işini iyi yapması için gereken nedir? Platon’a göre; "yönetmeyi üzerlerine almak için, karşılarında bir zor, bir ceza bulunması gerekir." ${ }^{11}$ Bu anlamda Platon’a göre devlet adamı doğası gereği buna uygun bir kişidir hem de "gerekli uzmanlık bilgisine sahip olan ve yurttaşlarının ahlaki gelişimlerini sağlamaktan başka bir şey düşünmeden çalışan kimsedir." ${ }^{22}$ Platon bu sınıflandırmaları yapar çünkü temelde gördügü mesele "gücün özellikle onu kullanmaya yetenekli olanların elinde kalmasıdır." ${ }^{33}$ Çünkü devletin zaten önde gelen biçimsel amacı tam da budur: Adalet ve adaletsizliği ortaya koyabilecek rasyonel ilkeleri oluşturmak. Bu ilkeleri oluşturup halka anlatabilecek, onlara öğretebilecek kişide aklıyla ön plana çıkan yönetici yani filozof krallardır.

Platon, kendi sisteminde herkese görevler vermiştir. Fakat görevler rastgele değil, herkesin kendi mayasına uygun şekilde seçilmiştir. Dolayısıyla iyi bir toplum da kendi mayasına göre davranan insanlardan oluşabilirdi. Eğer insanlara gelişigüzel haklar verirsek veya insanların ele geçirebileceği birtakım güçler ortada duruyorsa böyle bir toplum veya devlet yıkılmaya mahkumdur. İnsanlar kendi doğalarına göre seçilmeli ve bu da titizlikle yapılmalıdır. Çünkü doğası yönetmeye müsait olmayan birisi iktidara gelirse devlet çökmeye başlayacaktır. Burada bir noktaya dikkat çekmekte fayda var. Şimdi yukarıda ayrıntısıyla üzerinde durduğumuz gibi Platon insanların bir toplumda yeteneklerine göre işlerle uğraşmasını salık veriyor. Fakat bu fikir çoğu zaman Platon'u totaliterlikle suçlamaya neden olmaktadır. Öreğin Halis Çetin Platon'un ilk totaliter soylu düşünürlerden birisi olduğuna dikkat çeker. Çünkü Platon organizmacı bir anlayışla toplumu dizayn etme fikrindedir. Çetin’e göre:

"İnsanların bir organizmanın parçaları olduğu totaliter gelenek söylemi içerisinde insanların eşitsizliği de kendiliğinden ortaya çıkan bir sonuç olur. $\mathrm{Bu}$ yüzden Platon'un totaliter soylu geleneğe yaptığı en büyük katkılardan biri de budur. Toplumda bir kısım insanlar, insandaki beyin ve kafanın yaptığı işleri yaparken, diğer bir kısım insanlar da daha önemsiz görevleri yerine getirir." ${ }^{34}$

29 Platon, Devlet, 59.

30 Platon, Devlet, 38-39.

31 Platon, Devlet, 39.

32 Rowe, Platon: İdeal Devlet Biçiminin Arayışı, 21.

33 Rowe, Platon: İdeal Devlet Biçiminin Arayışı, 22.

34 Halis Çetin, Totaliter Soylu Gelenek (Ankara: Kadim Yayınları, 2010) 34-35. 
Platon’un bazı işleri veya o işi yapan insanların gereksiz olduğunu düşündüğünü ileri sürmek neredeyse imkansızdır. Öyle olsa bir toplumda sadece bir kesimin yaşaması gerektiğini düşünürken, diğerlerini hiç de önemsemezdi. Diğer taraftan bir yöneticiyi bir koruyucudan ayıran önemli bir fark yoktur, ikisi de kendi doğaları itibariyle uygun oldukları işlerle ilgilenirler. Böylece herkes kendine uygun işi yaptığ 1 için adalet de sağlanmış olacaktır. Platon'un devletin veya topluluğun çıkarlarını, kimliğini yok edercesine bireyin üstüne koyduğu söylenebilir. Fakat Rowe'un dikkat çektiği gibi "aşağı sınıftan olanlar bile, erdemin kendilerine uygun düşen kısmına sahip olacakları için 'güzel kent' Kallipolis'in üyeleri, Platon'un mutluluk anlayışın göre, gerçekten mutlu olacaklardır." ${ }^{35}$ Başka bir görüş ise bırakalım alt sınıfları, doğrudan filozofların kendi hayatlarını hiçe saydıklarını ileri sürer. Buna göre alt sınıflar kendi yaşamlarını ertelemezler:

“Tersine, yöneticiler, nesnel olarak neyin farklı kişilerin iyiliğine olduğu -hangi insan doğasına hangi mutluluğun uygun düştüğü- konusundaki bilgilerini, herkese iyi bir yaşam sunmak için kullanırlar. Gerçekten, Sokrates’in ütopyasında kendi mutluluklarını, en azından geçici olarak, feda eden biricik kişiler filozoflardır. Filozoflar, politik ödevler üstlenirken zihinsel yaşamı ertelemek zorunda kalmaktadırlar." ${ }^{36}$

Ayrıca Platon'un toplumu sınıflara veya tabakalara bölmesini bırakalım onun despotik veya otoriter yönetim hayalinin bir parçası olmasını aksine gayet toplumsal kaynaşmayı sağladığını savunan görüşler de vardır. Evet Platon toplumu üçe ayırır, "bunlar toplumu parçalamak şöyle dursun, aralarındaki bağımlılık ilişkileri nedeniyle, 'organik' bir dayanışma yaratarak toplumsal birliğin daha sağlam bir biçimde kurulmasını sağlamaktadır." 37

Son olarak Platon'un zenginlik ve yoksulluğa dair görüşlerine bakacak olursak, ona göre zanaatkarları veya daha genel olarak iş gören insanı işe yaramaz hale getiren en önemli şey, zenginlik ve yoksulluktur: "Çömlekçi zengin olunca, sanatıyla uğraşmak ister mi? ...gittikçe daha tembel, daha ilgisiz olmaz mı? Yani gün geçtikçe sanatında kötüleşme olur... Tersine çömlekçi yoksulluk yüzünden işi için gerekli araçları bulamazsa, hem yapacağı iş kötü olur..." ${ }^{38}$ Burada ise Platon, insanın toplumsal varlığının insanı belirlediğini veya şekillendirdiğini ileri sürüyor görünmektedir.

\section{Aristoteles'in İnsan Doğası ve Toplum Anlayışı}

Aristoteles, bir yanda eski görkemini kaybeden Atina’nın, bir yanda yeni oluşmaya başlayan, başka türlü bir "bilme paradigması"nın etkisi altında kendi sistemini kurmaya başlar. Bu değişim haliyle siyasete ve yönetim anlayışına da etki etmiştir. Bu etki nedeniyle bir kent -polis-, sadece insanların bir arada yaşadığı bir yer olarak değil; ölçü, denge ve Aristotelesçi "iyi” ilkeleriyle kurulmuş "iyi yaşamın” siyasal imka-

35 Rowe, Platon: İdeal Devlet Biçiminin Arayışı, 23.

36 Jeffrey Abramson, Minerva’nın Baykuşu: Batı Siyasi Düşünce Tarihi, çev. İbrahim Yıldız (Ankara: Dipnot Yayınları, 2013), 103.

37 Mehmet Ali Ağaoğulları, Kent Devletinden İmparatorluğa, 4. bs. (Ankara: İmge Kitabevi, Kasım 2004), 235.

38 Platon, Devlet, 111. 
nı olarak düşünülmeye başlanır. Bu anlamda Aristoteles'in, hocası Platon'dan farklı bir yöntem izlediğini söylemekte olasıdır. Özellikle hocasının idealar kuramını eleştiren Aristoteles, her şeyden önce bir duyumcu filozoftur. Aristotelesçi duyumculuğa göre, siyah denilen bir kavramın olması öncelikle siyah denilen bir şeylerin varlığını zorunlu kılar. Oysa Platoncu bakış açısına göre, siyahın kendisi siyah şeylerden önce gelir yani siyah öncelikle siyah ideasından pay alır.

Ayrıca Aristoteles'in, Platon'a, politikaya dört elle sarılanlara, ütopik düşünürlere ve müstakbel devrimcilere yönelik tutumu çoğu zaman kuşkuculuktur. Çünkü Aristoteles`e göre bunlar sonunda aynı hataya düşer ve insan doğasını dönüştürmek hususunda politikanın oynayabileceği rolü abartırlar. Genel olarak söylenecek olursa Aristoteles, siyasi ihtiraslarımızı ve radikal değişim yolundaki arzularımızı sınırlandırmanın kötü değil, iyi bir şey olduğu kanısındadır. ${ }^{39}$

Hocasıyla yöntemsel ve analitik olarak bu denli farklı olan Aristoteles, kendinden sonra birçok düşünce sistemini ve filozofu etkilemiştir. Özellikle Orta Çağ düşünürleri üzerindeki etkisi kayda değerdir. Birçok konuda ileri sürdüğü fikirleriyle kendisinden sonra birçok düşünürün kendi sistemini kurması için başvuru niteliği taşıyan Aristoteles'in fikirlerine başvurulan en önemli konulardan birisi de varlık üzerine yapmış olduğu çıkarımlardır. Aristoteles, her varlığın kendi özünde bir iyinin olduğunu ve varlığın bu iyiyi bulmaya yönelik eylemde bulunduğunu söyler. Fakat bu her varlık için söz konusu değildir:

“Gerçekten de hareketsiz varlıklarda bir hareket ilkesinin veya İyi'nin var olabileceğini nasıl düşünebiliriz? Çünkü kendinden ve kendi doğasından ötürü iyi olan her şey, bir erektir ve bu bakımdan o, aynı zamanda bir nedendir (çünkü diğer varlıklar bu iyi olana erişmek için varlığa gelirler ve vardırlar). Yine öte yandan, çünkü erek, bir eylemin varmak istediği amaçtır ve her eylem de bir hareketle birlikte bulunur. $\mathrm{O}$ halde hareketsiz varlıklarda ne bu hareket ilkesinin, ne de bir kendinde İyi’nin varlığı kabul edilebilir." ${ }^{40}$

Buradaki ayrım, varlığın devinim içinde olup olmamasıyla ilgilidir. Ayrıca Aristoteles'e göre "yerden, boşluktan ve zamandan bağımsız bir devinim olanaksızdır." ${ }^{41}$ Aristoteles, bu hareket ilkesini aynı zamanda doğanın içine de yerleştirir: "Doğa bir amaç, bir ereksel nedendir (çünkü kendilerinde sürekli devinim olan nesnelerin bir amacı var;) işte bu son nokta aynı zamanda ereksel neden." ${ }^{42}$

Bütün varlıklar kendi içindeki ereği gerçekleştirmek zorundaysa, o zaman insan da kendi içindeki iyiyi bulmaya yönelir veya kendi içindeki iyiyi ortaya çıkarır. İnsanın içindeki bu erek ise Aristoteles'e göre mutluluktur.

Peki, insan nedir, hatta özgür insan nedir? Aristoteles'e göre ereğini kendi içinde taş1yan ve bir başkası için var olmayan insana özgür insan denir. ${ }^{43}$ Fakat bunu söyleyerek

39 Abramson, Minerva’nın Baykuşu: Batı Siyasi Düşünce Tarihi, 10

40 Aristoteles, Metafizik, çev. Ahmet Arslan, c. 1. (İzmir: Ege Üniversitesi Basımevi, 1985), 161.

41 Aristoteles, Fizik, çev. Saffet Babür, (İstanbul: Yapı Kredi Yayınları, 1997), 93.

42 Aristoteles, Fizik, 59.

43 Aristoteles, Metafizik, c. 1, 88. 
insanın tek başına yalıtık olduğunu iddia etmez, aksine başka bir yerde dile getirdiği üzere Aristoteles’e göre insan doğal yapısı gereği toplumsal bir varlıktır. ${ }^{44}$ Başka bir yerde yazdığı üzere insanı birlikte yaşamaya yatkın bir varlık olarak düşündüğü görülmektedir: “...Hiç kimse bütün iyilere sahip olmayı tek kendisi için tercih etmese gerek, çünkü insan toplumsal, doğa gereği birlikte yaşamaya yatkın." ${ }^{45}$ Buradaki kasıt her insanın kendi içinde bulundurduğu cevherin herkese göre farklı olmasıdır. Buradaki erek ise en yüce mutluluğu elde etmektir. Buradan ulaşabileceğimiz en kısa sonuç, insanın kendi ereğini kendi içinde taşıması anlamında kendine yeter ve toplumsal bir varlık olduğudur.

Aristoteles'in insan anlayışına tekrar döneceğiz, ama öncelikle ona göre bir şeyin doğası derken neyi kastederiz önce buna bakalım. Aristoteles, herhangi bir şeyin yetkinleşme sürecinin tamamlanmış ürününe o şeyin doğası demektedir. İnsan, ev, aile, her şey o olmayı (kendi doğasına erişmeyi) amaçlar. ${ }^{46} \mathrm{O}$ zaman Aristoteles'e göre bir şeyin "doğa"sı onun ilk değil son durumudur. Bu, sonu hedefleyen gelişme veya büyüme süreci de ona göre "doğa”dır. İşte insanın gerçekleştirmesi gerektiğini düşündüğü iyi de bu doğasında olanla ilgilidir.

İnsanın iyiyi gerçekleştirmesine yeniden dönecek olursak, “o zaman devletin niteliği nedir” gibi bir soru nasıl yanıtlanır? Aristoteles, her devletin iyi bir amaçla kurulmuş bir topluluk olduğunu söyler. "İyi” diyor, çünkü: "bütün insanlar eylemlerinde iyi saydıkları şeyi elde etmeye çalışırlar, gerçekten. Öyleyse, bütün topluluklar şu ya da bu şeyi amaçladıklarına göre, toplulukların en üstünü ve hepsini kapsayanı da, en yüksek iyiyi amaç edinecektir." ${ }^{37}$ İçimizdeki iyiyi gerçekleştirmek ve mutluluğu elde etmek. İnsanın bütün yaptıklarının amacı da budur, Aristoteles'e göre: "Demek ki yapılanların amacı olarak mutluluk, kendisi amaç ve kendine yeter bir şey olarak görünüyor." ${ }^{8}$ Bu durumda insanın işinin ne olduğunu tespit etmemiz lazım. Bu, tek başına bir işle ilgileniyor olmamız gibi bir durum değildir, insanın bir meslek edinme dışında bu dünyada bulunma amacını içinde barındıran bir işinin olup olmadığını sorgular Aristoteles: "Marangozun, ayakkabıcının belli işleri ve yaptıkları vardır da, insanın bir işi yok mudur? Yani doğal olarak işsiz mi? Yoksa gözün, elin, ayağın ve genellikle parçaların her birinin bir işi olduğu göründüğü gibi, insanın da bunların ötesinde bir işinin olduğu ileri sürülebilir mi?" 49

Aristoteles'in insan doğasına dair görüşlerini onun diğer varlıklarla insan arasında getirmiş olduğu ayrıma dair düşüncelerinde de görebiliriz. Örneğin Aristoteles, insanla öteki hayvanlar arasına önemli bir ayrım koyar. Aristotelese göre, "insanla öteki hayvanlar arasındaki gerçek ayrılık, yalnız insanların iyi ile kötü’yü doğru ile yanlış’ haklı ile haksız'ı sezebilmeleridir." ${ }^{50}$ Aşağıda tartışılacağı gibi, bundan dolayı insanlar tek başına veya sürü halinde değil de bir devlet, yani polis altında bir arada

44 Aristoteles, Nikomakhos'a Etik, çev. Saffet Babür (Ankara: Ayraç Yayınevi, 1997), 10.

45 Aristoteles, Nikomakhos'a Etik, 193.

46 Aristoteles, Politika, çev. Mete Tuncay, (İstanbul: Remzi Kitabevi, 1975), 9.

47 Aristoteles, Politika, 7.

48 Aristoteles, Nikomakhos'a Etik, 10.

49 Aristoteles, Nikomakhos'a Etik, 10.

50 Aristoteles, Politika, 10. 
yaşarlar. Fakat Aristoteles için insanın dünyada canlı bir varlık olarak yaşıyor olması, insanı diğer varlıklardan ayırmak için tek başına yeterli değildir. Buradaki farkı ortaya koymak için, insanı farklı kılan şey ve insanın işi acaba ne olabilir? diye sorar ve "yaşamak bitkilerle ortak görünüyor, biz ise insana özgü olanı arıyoruz. Öyleyse beslenme ve büyümeyle ilgili yaşamı da bir yana bırakmalı" ${ }^{11}$ diye ekler. Eğer tek başına yaşamak, büyümek ve gelişmek yeterli değilse, bir duyuya sahip olması insanı diğer varlıklardan farklı kılabilir mi? Yani duyulara sahip yaşam yeterli midir? Bu da yeterli görünmez Aristoteles'e; çünkü duyular "at, öküz ve bütün hayvanlarla ortak görünüyor," diyerek karşı çıkar. O zaman geriye akıl ve akıl sahibi olarak insan kalıyor diyerek devam eder, "akıl sahibi olanın -bunun da akla boyun eğen olarak, bir de akla sahip olan ve düşünen olarak- bir tür eylem yaşamı kalıyor. Eylem yaşamından da iki türlü söz edildiğinden, bunun etkinlik halinde olan yaşam olduğu belirtilmeli; çünkü 'daha önemli' diye ona dendiği düşünülüyor.” ${ }^{52}$ Yani Aristoteles, insanın sadece duyumlara sahip olan veya sadece canlı bir varlık olmasıyla dünyada farklılaştığını düşünmez. İnsanı diğer bütün varlıklardan ayıran temel ayrım akıl sahibi olması ve bununla da etkinlik yaşamı içinde olabilmeyi başarmasıdır. Bu ufuk açıcı önerme günümüzde bile Arendt, Gorz gibi birçok düşünürün ilgisini çekmektedir.

Peki, etkinlik yaşamından kasıt nedir? Etkinlik yaşamında da önemli bir kıstas koyar Aristoteles, insanın işi ruhun akla uygun ya da akıldan yoksun olmayan etkinliğidir:

"Ve belirli bir işin ve bu işte yetkin olanın işinin aynı olduğunu söylüyorsak (örneğin gitarcının işi ile erdemli gitarcının işinin aynı olduğunu söylüyorsak, bunu da genel olarak her iş konusunda söylüyorsak buna o işteki erdemde üstün olmayı eklemek koşuluyla; çünkü gitarcının işi gitar çalmak, erdemli gitarcının ise iyi gitar çalmaktır); eğer bu böyle ise [ayrıca insanın işinin belli bir yaşam olduğunu, bu yaşamın da ruhun akla uygun etkinliği ve böyle eylemler olduğunu; erdemli insana yakışanın bunları iyi ve güzel bir biçimde yapması olduğunu; her şeyin ise kendine özgü erdeme göre iyi yapılırsa, iyi gerçekleştirilmiş olduğunu da ileri sürüyoruz], insansal iyi, ruhun erdeme uygun etkinliği olur." ${ }^{53}$

İnsanın, insansal iyiyi gerçekleştirmesi ve bunu da en iyi biçimde gerçekleştirmesi gerekliliği Aristoteles tarafından ileri sürülür. Fakat Aristoteles için bu işin, insan tarafından bir kez iyi yapılması önemli değildir. Önemli olan bu etkinliği, insanın yaşamının sonuna kadar devam ettirmesidir. Çünkü bir tek kırlangıcın baharı getirmediği gibi, ne de bir tek gün; aynı şekilde bir tek gün ya da kısa bir süre insanı kutlu ve mutlu kilmaz. ${ }^{54}$

Hatırlanacağı üzere Aristoteles insanın işinin belli bir yaşam olduğunu, bu yaşamın ise gelişi güzel değil, ruhun akla uygun etkinliği olduğunu ama erdemli insanın ise bütün bu yaşam etkinliğini iyi ve güzel biçimde yapması gerektiğini söylediğinden

51 Aristoteles, Nikomakhos'a Etik, 10-11.

52 Aristoteles, Nikomakhos'a Etik, 11.

53 Aristoteles, Nikomakhos'a Etik, 19.

54 Aristoteles, Nikomakhos'a Etik, 19-20. 
bahsedilmişti. Fakat Aristoteles, bir şeyin iyi olması için, o şeyin kendi erdemine göre yapılırsa iyi olacağını da ekler. Ayrıca Aristoteles, yukarıda da görüldüğü üzere, insansal iyiyi ruhun erdeme uygun etkinliği olarak tanımlar. Aristoteles, "iyi, ana çizgileriyle bu şekilde betimlenmiş olsun” deyip ekler: "Ana çizgileri iyi çizilmiş şeyleri işleyip ayrıntılarını düzenlemek herkesin yapabileceği bir iş gibi görünüyor; zaman böylelerini bulur ya da onlara iyi bir yardımcı olur." ${ }^{55}$ Görüldüğü üzere Aristoteles, her insanın, her işi iyi yapabileceğini düşünmez. Yani Aristoteles’e göre insan için iyi dediği şeyin ölçütü bir işi en iyi şekilde gerçekleştirmek ve bunu ömür boyu gerçekleştirebilmektir. Bu süreçte de zaman böylelerini bulacak veya yardımcı olacaktır. Bu önerme kendi içinde; hem metafizik hem de idealist öğeler taşımaktadır. Metafizik özü, insanın içine bir öz yerleştirmekten, idealist özü ise insanın dışında ona yardımcı olan bir zaman kurgusundan oluşmaktadır.

Aristoteles'in insan doğasına yönelik çıkarımları erdem üzerine yapmış olduğu tartışmalardan da anlaşılabilir. Aristoteles'e göre iki tür erdem vardır: Düşünce erdemi ve karakter erdemi. Düşünce erdemi, daha çok eğitimle oluşur ve gelişir; bu nedenle de deneyim ve zaman gerektirir. Karakter erdemi ise alışkanlıkla edinilir, adı da bu nedenle küçük bir değişiklikle alışkanlıktan [ethos] gelir. Buradan hareketle Aristoteles, "karakter erdemlerinden hiçbiri bizde doğa vergisi bulunmaz; çünkü doğal olarak bir özelliğe sahip olan hiçbir şey başka türlü bir alışkanlık edinemez" demektedir. ${ }^{56} \mathrm{Bu}$ sözle Aristoteles'in ne kastettiği kendi örneği üzerinden ele alınabilir. Aristoteles, “örneğin doğal olarak aşağı giden bir taşı, biri onu binlerce kez yukarı doğru atarak alıştırmaya çalışsa bile, taş yukarı doğru gitmeye alışamaz" der. Buradan hareketle şuraya ulaşır: "Doğal yapısı gereği başka türlü olan hiçbir şey de başka türlü bir alışkanlık edinemez. Demek ki erdemler ne doğal olarak ne de doğaya aykırı olarak edinilir; onları edinebilecek bir doğal yapımız vardır, alışkanlıkla da onları tam olarak geliştiririz." ${ }^{57}$ Yani diyor ki Aristoteles, bir şeyin olanaklarını daha önceden taşıyoruz, daha sonra da etkinlikleri gerçekleştiriyoruz. Aristoteles bu durumu aynı insanların duyularındaki, mesela görme ve işitmedeki bir nitelik gibi düşünür: "Biz birçok kez görmekten, birçok kez duymaktan bu duyuları edinmiş değiliz, tersine onlara sahip olarak kullandık, kullanarak sahip olmadık. Erdemleri ise, öteki sanatlarda olduğu gibi, daha önce etkinlikte bulunarak ediniriz; çünkü öğrenip yapmamız gereken şeyleri biz yapa yapa öğreniriz." ${ }^{58}$ Aristoteles şöyle örneklendirir bu durumu, mesela "ev yapa yapa mimar, gitar çala çala gitarcı oluyorlar; bunun gibi adil şeyler yapa yapa adil insan, ölçülü davrana davrana ölçülü, yiğitçe davrana davrana da yiğit insan oluruz." ${ }^{59}$ Böylece Aristoteles, etkinliğin sürekliliği ile insanın da iyiye yönelinebileceğini söylemiş olur.

Bütün bu tartışmalardan hareketle Aristoteles, iyi yönetimle kötü yönetimin farkına dikkat çeker. Aynı ilke yönetim konusunda da geçerlidir. Aristoteles'e göre yasa 
koyucular yurttaşları alıştırmakla iyi kılarlar. Bunu iyi beceremeyenler amaçlarına ulaşamazlar: "İyi yönetimlerin kötü yönetimlerden farkı da işte buradadır." ${ }^{60}$

Aristoteles, burada ortaya konulduğu gibi insanın bir şeyi yapa yapa, yani bir şeyi alışkanlık haline getirerek o şeyi öğrendiğini, o şeyi gerçekleştirmede iyi veya kötü olduğunu söyler; örneklendirdiği gibi, tehlikelere dayanan ve bundan hoşnut olan ya da üzülmeyen yiğit, üzülen ise korkaktır. Fakat burada önemli olan şey Aristoteles’e göre ölçülülüktür: Aynı aşırı ve eksik yapılan beden eğitiminin gücü yıpratması gibi, "içki ve yemekler çok fazla ya da çok az olduğu zaman sağlı̆̆ı bozar, dengeli olduğu zaman ise sağlı̆̆ meydana getirir, artırır ve korur. Her şeyden kaçan, korkan ve hiçbir şeye dayanamayan korkak; hiçbir şeyden hiçbir şekilde korkmayan, her şeyin üzerine giden cüretli olur.”'1

Doğal olarak iyi veya kötü olmayız diyen Aristoteles, her erdem neyin erdemiyse, o şeyin iyi durumda olmasını ve kendi işini iyi gerçekleştirebilmesini sağladığını söyler. Aristoteles bu çıkarımını şöyle örneklendirir: Sözgelişi gözün erdemi gözü ve onun işini erdemli kılar; çünkü gözün erdemi sayesinde iyi görürüz. Aynı şekilde atın erdemi atı erdemli kılar; iyi koşmasını, binicisini iyi taşımasını ve düşmanların karşısında kaçmamasını sağlar. ${ }^{62}$ Peki, bu her şeyde bulunan erdem insanın ne olmasını gerektirir? "İnsanın erdemi insanın iyi olmasını ve kendi işini iyi gerçekleştirmesini sağlayan huy olmalı"dır der. ${ }^{63} \mathrm{O}$ zaman Aristoteles'in şöyle bir çıkarımda bulunduğu rahatlıkla söylenebilir: Nasıl ki insanın gözü var ve görüyor, o zaman insanın erdemli olmasını da sağlayan bir "şey" var. Ha bazılarında bu yoktur, o durumda da o insanlar erdemsiz olurlar. Aslında birazdan görüleceği üzere Aristoteles tüm bunları tartışarak doğal olarak insanların bazıları yöneten bazıları da yönetilen olmalıdır diyecektir. Bu tartışmanın ayrıntısına geçmeden önce eksik bıraktığımız bir kaç noktayı tartışmakta fayda var.

Aristoteles tarafından eylemlerde aşırılığın veya eksikliğin özellikle kaçınılması gereken bir şey olduğuna değinilmiştir. İnsanın kendi işini iyi yapmasının koşulu olarak da yine aynı ilkeyi öne sürüyor: "Gerektiği zaman, gereken şeylere, gereken kişilere karşı, gerektiği için, gerektiği gibi bunları yapmak orta olandır ve en iyidir, bu da erdeme özgüdür. ...Demek erdem bir tür orta olmadır; ortayı amaç edinir." ${ }^{\prime 4}$ Bu fikre Platon'un kaynaklık ettiği açıktır. Platon da "bir insanda en büyük güç akıl ve ölçülülükle birleştiği zaman, en iyi devlet düzeni ve en iyi yasaların oluşumu gerçekleşir, başka türlü olamaz" demektedir. ${ }^{65}$ Böylece erdemin, Aristoteles için tercihlere ilişkin bir huy olarak görüldügünü ve bir ortayı bulma yetisi olarak düşünüldüğü söylenebilir. Şu alıntıda da dikkat çektiği gibi, "Akıl tarafından ve aklı başında insanın belirleyeceğiyle belirlenen, bizle ilgili olarak orta olanda bulunma huyudur. Bu, biri aşırılık, öteki eksiklik olan iki kötülüğün ortasıdır; kötülük etkilenimlerde ve eylem-

60 Aristoteles, Nikomakhos'a Etik, 24. 
lerde gerekenden aşırısı ya da eksiğidir, erdem ise ortayı bulma ve tercih etmedir." ${ }^{66}$ Fakat Aristoteles'in yukarıda "akıl tarafından aklı başında insanın belirleyeceği..." demesi, insanın aklıyla belirlediği her şeyi yapmakta özgür olduğunu veya her şeyin bir ortasının bulunduğunu düşündürebilir. Fakat bu yanlış bir çıkarım olur. Zira, Aristoteles'e göre her eylem ile her etkilenimin ortası olması söz konusu değildir; nitekim bunlardan kimileri, ona göre, adlarında kötülük barındırır; "sözgelişi hasetlik, arsızlık, kıskançlık; eylemler içinde de zina, hırsızlık, adam öldürme. Çünkü bütün bunların ve bu gibi şeylerin aşırılıklarının, eksikliklerinin değil, kendilerinin kötü olduğu söylenir." ${ }^{67}$ Çünkü Aristoteles`e göre, bunlarda isabetli olmak olanaklı değildir, hep yanlışa düşmek söz konusudur:

"Bunların iyi olması-olmaması, zina konusunda olduğu gibi, kimle ne zaman yapmak gerektiği söz konusu değildir; bunlardan birini yalnızca yapmak yanlış yapmak olur. Aynı şekilde haksızlık yapmak, korkak olmak, haz peşinde koşmak konusunda da orta olma ve aşırılık-eksiklik olduğunu ileri sürmek söz konusu değildir; çünkü bu şekilde aşırılığın ve eksikliğin ortası diye aşırılığın aşırılığı ile eksikliğin eksikliği olacak." ${ }^{68}$

O zaman şu soruyu sormak gerekiyor; insan doğasında bunlar yoksa, insan nasıl edinir? Bir şeyin alışkanlık haline getirilmesi sadece kişiye ait midir? Kişinin dışında, kişinin mevcut durumu onun ne yapacağını koşullandırır mı? Örneğin hiç parası olmayan birisinin sadaka veremeyeceği veya yoksul kişinin dilenebileceği gibi... Bu alışkanlık haline getirdiğimiz şeyler bunları da kapsamakta mıdır? Ne yazık ki tartışmaz bunları Aristoteles. En son aşamada şuraya getirip dayamaktadır tartışmayı: "O halde 'adil işler yaparak kişi adil, ölçülü işler yaparak kişi ölçülü olur' sözü yerindedir. Bunları yapmayınca da hiç kimsenin hiçbir zaman iyi olması söz konusu olamaz." 69 Yani iyi dediğimiz şey bir toplumda iyi olarak görülen şeyi yapmak mıdır, yoksa bu iyi bütün çağlar boyu kendini koruyan bir "töz" müdür? Mesela feodal dönemin davranışı olarak ölçülülük; kendine yeteni, mevcut ihtiyacını karşılayanı almak, fazlasına göz dikmemek mi iyi bir davranıştır; yoksa kapitalizmdeki gibi fazla mal göz çıkarmaz mantığıla biriktirmek, ihtiyacın ne olduğunun bilinmediği bir toplumda sınırsız bir mülk edinme isteği duymak mı, iyidir? Hegel'in yapmış olduğu bir çıkarım üzerinden soracak olursak, bir totem karşısında içi dolan insan, secdeye eğilen bir başın yaşadığı huzur veya bir başka inançtaki bir başka ritüel... Hepsi bulunduğu toplumda değerli iken bir başka toplum için saçma, yararsız, belki de sapkıncadır. Bir toplumda iyi olarak görülen şey bir başka toplumda kötüdür. Bu durumda bizi iyi kılan şey nedir? Değişmez, evrensel bir töz var ve onu gerçekleştirmemiz mi, yoksa bulunduğumuz toplumun genel olarak iyi gördüğü şeyi gerçekleştirmemiz mi? Fakat bu soruların tam bir yanıtını bulmak zor görünüyor. Böylece Aristoteles'in erdem dediği, iyi dediği her şey, kişiye indirgenirken bile, insanın kendinden ve insanın maddi koşullarından kopup bağımsız bir saltanat kurmuş görünüyor. İşte Aristoteles`ten itibaren düşünülmeye başlanan, insanın düşüncesinin ve eyleminin 
bütün sonuçlarının kesinliği ve insan eyleminin insan için iyi olup olmadığı sorununun onun -insanın- dışından belirlendiği yönündeki fikirlerin bu metafizik özüne kesin olarak son verecek olan düşünür Hegel'dir.

Peki, Aristoteles için yöneten ve yönetilen ilişkisi veya daha genel anlamda siyaset anlayışı nedir ve -bu çalışma için asıl önemli olan- kendi fikrinde varsaydığı insan doğası nasıl bir politik pratiği ön görmektedir? Yöneten ve yönetilen insanları nasıl konumlandırır devletinde? Belki soruya Aristoteles'in ne yanıt verdiğine geçmeden önce şu çıkarıma değinmekte fayda var. Modern toplumun insanı için yönetim, politika insanı kısıtlama aracı veya bir baskı aracı gibi görünse de Aristoteles için bu böyle değildir. Politik yaşam, Aristoteles’e göre "bizi bütünüyle insan yapan yetileri pratiğe dökmek ve mükemmel hale getirmek üzere kişileri özgür kılar." ${ }^{30}$ Şimdi sorunun yanıtını ayrıntılı ele alacak olursak, Aristoteles'e göre, nasıl ki doğal olarak çift çift birleşme varsa, örneğin üreme için erkekle dişinin birliği zorunluysa -çünkü öteki olmadan biri etkisiz kalır- ve aynı zamanda bu düşünülerek yapılmış bir seçme değilse -çünkü doğa hayvanlara da bitkilere de kendi benzerlerini çoğaltma isteğini vermiştir-, aynı şekilde "yönetenle yönetilenin birleşmesi de, tıpkı bunun kadar gereklidir; bunların bir araya gelmelerinden amaç, ortak güvenliklerinin korunmasıdır." ${ }^{71}$ Aristoteles'in yöneten ve yönetilenin bir araya gelmesinin nedenini güvenlik ilişkisine bağladığı söylenebilir. Fakat yöneten ve yönetilen kimdir niçin yönetici veya yönetilendir insanlar? Bunu da insan doğasıyla açıklar. Ayrıca Aristoteles, bu yöneten ve yönetilen olma pozisyonlarını da bir doğal zorunluluğa bağladığına dikkat çekmekte fayda var. Ona göre: "Gereken şeyleri zekasıyla önceden görebilen bir kimse, doğaca yönetici ve efendidir, oysa beden gücüyle bunları yapabilen bir kimse doğaca köledir, yönetilenlerden biridir." ${ }^{72}$ Fakat bu doğal zorunluluk sadece bir devletteki yöneten ve yönetilen ilişkisinde ortaya çıkmaz, bazı toplumlarda diğer toplumlardan üstündür. Buradan hareketle Yunan'l1-olmayanları barbar topluluklar olarak gördügü için "Hellenlerin barbarları yönetmesi uygundur” yönündeki sözü olumlar. ${ }^{73}$ Aristoteles' in buradaki akla sahip olan kişiler dediği "barbar" olmayan Yunanlardır. Yani Aristoteles, kişilerin ve ırkların doğadan kaynaklı üstün olduklarına inanmaktadır. Fakat buradaki ayrıntı şudur; yukarıda Aristoteles, yöneten ve yönetilen ilişkisinin nedenini güvenlikle açıkladı ama daha sonra birilerinin efendi birilerinin ise köle olmasının doğal olarak karşılanmasını söyledi. O zaman mesele sadece güvenlik değil, efendinin ve kölenin bir toplumda meşru görülmesinin de yolunu açmış oluyor Aristoteles. Nitekim Aristoteles'in göstermiş olduğu bu ayrım, çağlar boyunca bir sömürü ilişkisini de meşru görmenin aracı haline gelmiştir. Konumuz dışına çıkmadan belki değinmekte fayda var Aristoteles'in böyle bir çıkarıma gitmesinin nedeni insanı maddi koşullarından soyutlamasıdır. Bu maddi koşullardan soyutlandığı için insanca olan hemen her şey bir doğal olma kisvesiyle meşru zemine çekilebilmektedir. Örneğin: Aristoteles, "gereken şeyleri zekasıyla önceden görebilen bir kimse, doğaca yönetici ve efendidir, oysa beden gücüyle bunları yapabilen bir

70 Abramson, Minerva’nın Baykuşu: Batı Siyasi Düşünce Tarihi, 134.

71 Aristoteles, Politika, 8.

72 Aristoteles, Politika, 8.

73 Aristoteles, Politika, 8. 
kimse doğaca köledir, yönetilenlerden biridir" diyerek yöneten ve yönetilen ilişkisini maddi bağlamından, yani ilişkilerden koparıp ele alır. Bu mantık çağlar boyu işlevsel bir araç olarak kullanılmıştır. Aynı mantığın, Birleşik Devletler'de de devam ettiği görülmektedir. Birleşik Devletler'de köle düzeninin savunuculuğunu yapan, O'Connor adlı avukatın, 19 Aralık 1859 tarihinde New York'ta yapılan bir mitingde, "Güneye Adalet" sloganı altında yapmış olduğu bir konuşmaya Marx şöyle yer vermektedir:

"Büyük bir alkış tufanı arasında, "şimdi baylar," diyor, "zenciyi bu köle durumuna koyan şey, doğanın kendisidir . ...O kuvvetlidir ve çalışma gücüne sahiptir, ama, bu gücü yaratan doğa, ondan, hem yönetme yeteneğini ve hem de çalışma isteğini esirgemiştir." (alkışlar.) "Bunların her ikisi de ondan esirgenmiştir. Ve ondan bu çalışma isteğini esirgeyen doğa, bu isteği zorla yaratacak, hem kendisi ve hem de onu yönetecek efendisi için yararlı bir yaşam sürebileceği bir ortamda hizmet etmesini sağlayacak bir efendi ihsan etmiştir. ... İnanıyorum ki, zenciyi doğanın uygun gördüğü durumda bırakmak, kendisini yönetecek bir efendi vermek asla adaletsizlik değildir ...karşıllk olarak onu çalışmaya zorlamak ve onu yönetmek, hem kendisi ve hem de toplum için yararlı duruma getirmek yolunda emek ve yeteneğini harcayan efendisine hakkı olan bir karşıllk vermeye zorlamak, haklarından herhangi birisini elinden almak demek değildir." ${ }^{34}$

Mevcut durumun görüntüde ele alınması gerçekten de her çağda işe yarar bir durumdur. Çünkü bir durumun bir betimlemesi veya doğallık kisvesi altında ele alınması o duruma bir meşruiyet zemini açar.

Peki, devlet nasıl oluşur ve Aristoteles, devletin ne olduğunu nasıl açıklar? Aristotelese göre bir toplumda en alt örgütlenme veya birleşme biçimi ailedir: Bir ev ve bir kadınla bir öküz edinen adamın kurduğu. Bundan sonraki aşama ona göre köydür: Köylerde günlük gereksinimlerin ötesinde birçok ihtiyacı karşılamak için bir araya gelen evler yani aileler bu köyleri oluşturur. Ve son birleşme de çeşitli köylerden oluşan şehir ya da devlet yani polis'tir. Hatırlanacağı üzere yukarıda Aristoteles'in bir şeyin yetkinleşme sürecinin tamamlanmış ürününe o şeyin doğası dediğine değinmiştik. İşte burada son birlik olarak gördüğü birlik, polistir. Yani süreç tamamlanmıştır: "Kendi kendine yeterliliğe erişilmiş ve böylelikle, yaşamın kendisini sağlamak için başlamışken, şimdi iyi yaşamı sağlayabilecek bir duruma gelmiştir. Bundan dolayı, içinden çıtığı daha eski topluluklar nasıl doğalsa, şehir-devleti de öylece yetkinlikle doğal bir topluluk biçimidir."75 Yani Aristoteles'e göre bu birlik -polis veya şehir-devleti- ötekilerin amacıdır ve bunun doğasının kendisi bir amaçtır. Buradan hareket eden Aristoteles "devletin doğada var olan şeyler sınıfına girdiği ve insanın doğadan siyasal bir hayvan olduğu" sonucuna ulaşır. ${ }^{7}$ Ayrıca Aristoteles, insanın politik bir toplumda birlikte yaşamasının ona erdem ve mutluluk kattığını düşünür: "Politik bir toplulukta yurttaşılık, yaşamımıza erdem ve mutluluk katması bakımından dostluğa

74 New-York Daily Tribune, 20 Kasım, 1859, s. 7-8.den aktaran Karl Marx, Kapital: Bir Bütün Olarak Kapitalist Üretim Süreci, c. 3. çev. Alaattin Bilgi. 3. bs. (Ankara: Sol Yayınları, 1997), 339.

75 Aristoteles, Politika, 9.

76 Aristoteles, Politika, 9. 
benzer; erdem ve mutluluk da kişinin kendi benlik duygusu karşısında vazgeçilmez hale gelen bir yaşam tarzına duyduğu bağlılık ve dayanışma duygusu gibi hazları deneyimlemekten kaynaklanır." ${ }^{\prime 7}$ Fakat yinede yurttaşlık ilişkisiyle topluluğuna bir aidiyet erdemi yaşamayan insanlar varsa eğer bunlar ancak kendilerinde eksik kişilerdir. Bir başka deyişle, "bizatihi insan doğası, mutluluk ile sadece bir topluluğun üyeleri için mevcut olan belli erdemler arasındaki bağlantıya gerekçe kazandırır.” ${ }^{8}$

Böylece Aristoteles insanın, doğasından kaynaklı devlet ve toplum içinde yaşamak istediğini ve yaşamak zorunda olduğunu söylemiş olur. Şehri ve devleti olmayan birisi de ona göre, düpedüz bahtsızlığından değil de doğası gereği, ya fazla iyidir ya fazla kötü, ya insanlığın altındadır ya üstünde. Bundan kastı şudur Aristoteles`in: İnsanın tek başına kalması doğası gereği savaşa düşkün bir kişi olmasındandır; tek başına kalmış bir dama taşı gibi hiçbir işbirliğine girmez. Fakat Aristoteles`e göre “önümüzdeki, yalnızca bir işbirliği yapıp yapmama sorunu değildir; çünkü besbelli ki, insan, arının ya da topluluk içinde (sürü halinde) yaşayan başka herhangi bir hayvanın olmadığı anlamda bir siyasal hayvandır." 79 İnsan aynı zamanda bir siyasal hayvan olmak zorundadır da çünkü yukarıda da değindiğimiz gibi yalnızca insanlar iyiyle kötünün, haklıyla haksızın farkına varabilmektedir. Bundan dolayı politik yaşam insanlık durumu nezdinde doğal ve kaçınılmazdır. Aristoteles’e göre "insanların sitelerde yaşamaları ve birbirleriyle ortak ya da paylaşılmış bir fayda etrafında ilişki kurmaları onların evrensel doğasıdır." ${ }^{80}$ Buradan hareketle siyasal yaşamın insanlar için doğal olduğunu söyleyebiliriz. Çünkü bu yaşam "insan doğasının en ayırt edici özeliği olan konuşma ya da akıl kapasitesi niteliğindeki potansiyelin gerçekleştirilmesine izin verir." ${ }^{\prime 1}$ Hayvanlar iyiyle kötüyü ayırt edemedikleri için politik bir toplum kuramazlar. Tanrılar politik topluluklarda yaşamaya gerek duymazlar, çünkü tanrı olmak demek kendi başına eksiksiz olmak, kendi kendine yeterli olmak demektir. "Fakat insanlar kendi mutluluklarını ancak başkalarıyla ilişki kurarak olgunlaştırabilirler; bunun açık bir örneği dostluktur: dostluk, bizim tek başımıza başaramayacağımız bir iyilik katar yaşamımıza." 82

Görüldügü üzere Aristoteles de Platon gibi yönetilen ve yöneten ilişkisini bir doğallık olarak görmektedirler. Aristoteles kendine göre bir mantık oluşturmuş ve hocası Platon'dan bir çok noktada ayrılmış olsa da insanın topluluk içinde yaşaması ve o toplumdaki yönetim ilişkilerinin niteliği onunla benzeşmektedir.

\section{Sonuç}

Platon insanın doğuştan bir mayayla doğduğunu ileri sürer. Bundan dolayı bir toplum veya devletin en önemli görevini insanın mayasının ne olduğunu tespit etmek olarak belirtir. Aksi taktirde insanlar kendi yeteneklerine uygun olmayan işlerle

\footnotetext{
77 Abramson, Minerva'nın Baykuşu: Batı Siyasi Düşünce Tarihi, 115. 78 Abramson, Minerva'nın Baykuşu: Batı Siyasi Düşünce Tarihi, 115.

79 Aristoteles, Politika, 9.

80 Abramson, Minerva’nın Baykuşu: Batı Siyasi Düşünce Tarihi, 115.

81 Larry Arnhart, Siyasi Düşünce Tarihi, Plato’dan Rawls'a, çev. Ahmet Kemal Bayram (Ankara: Adres Yayınları, 2004), 56.

82 Abramson, Minerva’nın Baykuşu: Batı Siyasi Düşünce Tarihi, 115.
} 
uğraşttğı için o devletin veya toplumun yıkılması veya bozulması da uzun sürmez. Mayasının ne olduğu tespit edilen insan mayasına göre uygun eğitim alarak kendi mayasına uygun olarak gelişim sağlar. Fakat bu eğitim -unutulmamalıdır ki- Platon’a göre insanın ne olduğunu değiştiren veya belirleyen bir özelliğe sahip değildir. $\mathrm{Bu}$ eğitim insanın özünün keşfedilmesiyle ona uygun olarak kişinin uzmanlaştırıldığg bir eğitimdir. Bu anlamda Platon öz itibariyle insanın değişmeyeceğini ileri süren ilk düşünürlerden biri olarak ele alınabilir. Diğer taraftan şuraya dikkat çekmesi de kayda değerdir; insanlar eğitimle aynı anda bir sürü şey de olamazlar. Ayrıca bir insanın her şeyde başarılı olacağı da düşünülmez, yani bir insanın aynı zamanda hem şair, hem de oyuncu olamayacağını söyler. Diğer taraftan Platon’un insanın tek yönlü gelişim sağlayabileceğini düşündüğü görülür. Ayrıca toplumun temelini "insanın tek başına kendi kendine yetmemesi, başkalarını gereksemesi olarak düşünür. Platon’a göre toplumun kurulmasında başka bir sebep yoktur. Platon, kendi sisteminde herkese görevler vermiştir. Herkes kendi mayasına göre seçilir. Dolayısıyla iyi bir toplum da kendi mayasına göre davranan insanlardan oluşabilir. Eğer insanlara gelişigüzel haklar verirsek veya insanların ele geçirebileceği birtakım güçler ortada duruyorsa böyle bir toplum veya devlet yıkılmaya mahkumdur. İnsanlar kendi doğalarına göre seçilmeli ve bu da titizlikle yapılmalıdır. Çünkü doğası yönetmeye müsait olmayan birisi iktidara gelirse devlet çökmeye başlayacaktır. Aynı anlayış çok az farkla Aristoteles'in anlayışında da devam eder.

Aristoteles, hocası Platon'dan idealar dünyası gibi bir dünyayı varsaymayarak ayrışsa da birçok ortak noktası bulunmaktadır. Fakat Aristoteles'i Platon'dan ayıran en önemli ayrım varlıkları ereklerle açıklamasıdır. Aristoteles, insanın içine bir erek yerleştirir ve ona göre bütün varlıklar kendi içindeki bu ereği gerçekleştirirler. Doğa bir amaç, ereksel nedendir, ona göre. Bundan dolayı herkes kendi ereğine göre devinim gerçekleştirir. Aristoteles, herhangi bir şeyin olgunlaştığı yetkinleştiği son haline o şeyin doğası demektedir. Yani bir meşe palamudunun doğası meşe olmaktır ama o meşe palamudunun nasıl bir meşe olacağı anca onun olgunlaşmasıyla anlaşlabilir. Aristoteles bu anlayışı her şeye uygular. Böylece Aristotelesıe göre bir şeyin “doğa"sı onun ilk değil ulaşmış olduğu son durum olarak kavranır.

$\mathrm{Bu}$ tartışmaların yanı sıra Aristoteles ayrıca, insanın bu dünyalığının ne olduğunu da ortaya koymaya çalışır. Yaşamak ve duygulanmak diğer varlıklarla aynı özellikler olduğuna göre insan ancak aklıyla diğer varlıklardan ayrılabilir. Diğer taraftan insan, insansal iyiyi ortaya koyması gereken bir varlık olarak düşünülür. Ama bu iyi Aristoteles’e göre bir kez değil ömür boyu ortaya konulması gereken bir şeydir. İnsanın ortaya koyacağı şeyi onun özünde bulunan bir noktaya çeker Aristoteles. İnsanın içindekini ortaya koymasının imkanını ise hiç tartışmaz. İyiyi gerçekleştirmek için bir araya gelen insanlar toplumu ve devleti -polis'i- oluşturur. Ama Aristoteles burada Platon’u izleyerek bazılarının doğası gereği yönetici bazılarının ise yönetilen olması gerektiği ayrımına gider. Böylece siyaset teorisinde birçok kere karşımıza çıkacak olan bir duruma meşruiyet sağlamak için doğaya referans verme geleneği de başlamış olur. 
Gerek Platon'un gerekse Aristoteles insanların birbirleriyle ilişkiye girmeleriyle belirli görünümler kazandıklarını göz ardı ederler. İkisi de var olan durumdan hareketle insana belirli bir "doğa" atfetmektedirler.

\section{Kaynakça}

Abramson, Jeffrey. Minerva’nın Baykuşu: Batı Siyasi Düşünce Tarihi, çev. İbrahim Yıldız. Ankara: Dipnot Yayınları, 2013.

Ağaoğulları, Mehmet Ali. Kent Devletinden İmparatorluğa. 4. bs. Ankara: İmge Kitabevi, Kasım 2004.

Aristoteles. Fizik. çev. Saffet Babür. İstanbul: Yapı Kredi Yayınları, 1997.

Aristoteles. Metafizik. çev. Ahmet Arslan. c 1. İzmir: Ege Üniversitesi Basımevi, 1985.

Aristoteles. Nikomakhos'a Etik. çev. Saffet Babür. Ankara: Ayraç Yayınevi, 1997.

Aristoteles. Politika. çev. Mete Tuncay. İstanbul: Remzi Kitabevi, 1975.

Arnhart, Larry. Siyasi Düşünce Tarihi, Plato'dan Rawls'a. çev. Ahmet Kemal Bayram. Ankara: Adres Yayınları, 2004.

Çetin, Halis. Totaliter Soylu Gelenek. Ankara: Kadim Yayınları, 2010.

Marx. Karl. Kapital: Bir Bütün Olarak Kapitalist Üretim Süreci. c. 3. çev. Alaattin Bilgi. 3. bs. Ankara: Sol Yayınları, 1997.

Platon. Devlet. çev. Sabahattin Eyüboğlu-M. Ali Cimcoz. 3. bs. İstanbul: Remzi Kitabevi, 1975.

Platon. Yasalar. çev. Candan Şentuna-Saffet Babür. c. 2. 2. bs. İstanbul: Kabalcı Yayievi, 1998.

Rousseau. Jean-Jacques. Yalnız Gezerin Hayalleri. çev. Reşat Nuri Darago. İstanbul: MİV, 1944.

Rowe, Christopher. "Platon: İdeal Devlet Biçiminin Arayışı”, Siyasal Düşüncenin Temelleri. der. Brian Redhead, çev. Erkan Akın, İstanbul: Alfa Basım Yayın, 2001.

Ruby, Christian. Siyaset Felsefesine Giriş, çev. Aziz Ufuk Kılıç. İstanbul: İletişim Yayınları, 2012.

Sabine, George. Siyasal Düşünceler Tarihi 1: Eski Çă̆-Orta Çă̆, çev. Harun Rızatepe. Ankara: Türk Siyasi İlimler Derneği Yayını, 1969.

Tannenbaum, Donald. Schultz, David. Siyasi Düşünce Tarihi: Filozoflar ve Fikirleri. çev. Fatih Demirci. 4. bs. Ankara: Adres Yayınları, Kasım 2008.

TÜBA, Ulusal Açık Ders Malzemeleri, Eski Yunan'da Siyasal-Sosyal-Kurumsal Yapı, Yöntem ve Teoriye Dair, Haz., Bican Şahin, (1997), 7. (erişim 28.08.2016).

Zabcı, Filiz. Büyük Sokratesçi Okullarve Siyaset. Sokrates'ten Jakobenlere Batida Siyasal Düşünceler. Ed. Mehmet Ali Ağaoğulları. 5. Bs. İstanbul: İletişim Yayınları, 2015. 


\title{
Human Nature and the Notion of Society in Ancient Greek Political Thought: Plato and Aristotle
}

\author{
OLKAN SENEMOĞLU
}

\begin{abstract}
This study focuses on the human nature and social understanding of Plato and Aristotle. The way how these two philosophers explain the human nature and society and the place of the interferences of human nation and society in their understanding of management in the political theories is discussed. Accordingly, Plato and Aristotle agree on the notion that people have certain characteristics inherently. Similarly, they defend the same point of view about people who are born with certain talents and about the necessity of developing these talents by education they receive. On the other hand, both philosophers has the same way of raising awareness in the society. Both Plato and Aristotle believe that it is hard to live in the society as people are not self-sufficient living-things and they always need others. Having a look at the differences between Plato and Aristotle, Aristotle does not talk about the world of ideas assumed by Plato. In addition, he says that every person has a goal inside to perform the best. Thus, he gets the idea that the state established by gathered people is a good state. Plato thinks that people should do work and receive education according to their background in the state model according to him, while Aristotle believes that some people should become administrators as they can directly predict everything with their innate intelligence and some people should become administrated as they have innate physical strength.
\end{abstract}

Keywords: Platon, Aristotle, Human, Human nature, Society, State, Government. 